\title{
THE ENVIRONMENTAL IMPACT OF POULTRY PRODUCTION
}

\author{
V. Rodić ${ }^{1}$, L. Perić ${ }^{2}$, M. Đukić-Stojčić ${ }^{2}$ N. Vukelić ${ }^{1}$ \\ ${ }^{1}$ Department of Agricultural Economics and Rural Sociology, Faculty of Agriculture, Novi Sad, \\ Trg D. Obradovića 8, Republic of Serbia \\ ${ }^{2}$ Department of Animal Husbandry, Faculty of Agriculture, Novi Sad, Trg D. Obradovića 8, Republic \\ of Serbia \\ Corresponding author: rodicv@polj.uns.ac.rs \\ Review paper
}

\begin{abstract}
The main aim of the animal production is to produce animal proteins of high value in a sustainable manner. However, sustainability is not easy to define. It is a complex phenomenon, which includes integration of economic, social, and environmental dimensions of the certain production, within a given socio-economic context. In this respect, poultry production meets first two dimensions - it provides affordable dietary item for consumers and profit for producers. It additionally generates up and downstream investment opportunities and it contributes to the development of the local economy. However, with the concentration of poultry production and increase in operation size, considerable environmental problems have occurred. During the last several decades, the environmental impact of the poultry production has received an ever-growing attention. Nowadays, producers are under heavy pressure, from different fronts, to minimize the impact of their production on the environment and to adopt welfare friendly practices. The major challenges, which will affect animal production in the future, will likely deal with the environment. In this paper, the environmental impact of poultry production and the differences in this respect between the different production systems are presented.
\end{abstract}

Key words: poultry, sustainability, environment, impact, management

\section{Introduction}

During the last several decades, sustainable development has become one of the most important developmental priorities worldwide. Although the concept of sustainable development was officially promoted in the late $1980 \mathrm{~s}$, there is still no precise definition of this phenomenon (Daly, 1996; Atkinson et al., 2007). Nevertheless, there is a consensus among the authors that each economic activity depends on the global ecosystem (for its resources and for the absorption of pollutants) and that sustainable development is possible only if an integration of 
three different dimensions - economic, social and environmental is achieved (Jovanović-Gavrilović, 2003; Rodić et al., 2007a; Boggia et al., 2010).

As poultry production provides an affordable dietary item of a good quality for consumers and profit for producers. Additionally it generates up and downstream investment opportunities and it contributes to the development of the local economy. Therefore, one can say that it clearly meets first two dimensions (economic and social) of sustainability. However, intensification, concentration, and an increase in operation size, have been coupled with some detrimental environmental consequences (Rae, 1999; Wossink and Wefering, 2003; Rodić, 2006; Rodic et al., 2007a). Poultry is increasingly seen as a production that is not environmentally friendly and treated either as a pressure (in the "Pressure-StateResponse" models), or as a driving force (in the "Driving Force-Pressure-StateImpact-Response" models) (Willeke-Wetstein, 1998; OECD, 2003; Belini, 2005; Kostić and Rodić, 2009). As a result, producers are nowadays under intense pressure, from different fronts, to minimize the impact of their production on environment. According to Tabler (2007), the major challenge affecting animal production in the future will be environmental.

In the paper, the environmental impact of poultry production and the differences in this respect between the different production systems are presented.

\section{Poultry production as a polluter}

Driven by economic efficiency, poultry production, like everything else in market economy, has been significantly developed and changed over the last several decades. Global poultry population has grown from 4.2 billions birds in 1961 to 17.8 billion birds in 2005 (Hegg, 2006). Due to the increase in operational size, the concentration, and the intensification of poultry production, its off-site impacts have been considerably increased. Consequently, the public's perception of farmers is changing, and the public is less and less tolerant to those negative impacts (Tabler, 2007). As a result, environmental regulation is increasingly developing worldwide and poultry producers have to comply with it. What always should be bear in mind is that people, not animals, are the ones who pollute, ignoring environmental constraints when managing their operations (Rodić et al, 1999; Rodić et al., 2007b).

Poultry production adversely affects the environment in numerous ways through poor management of manure and litter, waste streams from processing plants (blood, bones, feathers, etc), birds' carcasses, dust, insects, odour, etc. Furthermore, intensive poultry production is held responsible for the emission of greenhouse gasses, acidification, and eutrophication.

The environmental impact of poultry production depends on numerous factors, among which are farm size, production system, diet composition, type of bedding used, etc. It is well known that, if properly managed, waste generated in the poultry 
production, especially manure and litter, could be a valuable resource, i.e. it could be used as fertilizer, soil conditioner, animal feed, or energy source (Nahm, 2000). However, thanks to the large amount of waste generated (which exceed crop fertiliser requirements), content of harmful elements (such as heavy metals, pesticide residues, pathogens, pharmaceuticals, etc.), and/or unwisely management, poultry waste is often polluter instead of the valuable resource. Thus, producers have to search for environmentally sound ways of waste disposal, which inevitably affects their income.

Interest in using poultry manure and litter as a soil fertilizer for crop production has emerged in parallel with rising interest in alternative agricultural production systems, firs of all organic production. Poultry litter contains significant amounts of nutrients essential for plant growth (Table 1). Its chemical composition can vary widely depending on the type and category of poultry, type and quantity of bedding used, environmental conditions in the facility, feed source, handling of manure, etc.

Table 1. Nutrient composition of poultry litter (modified according to Dick et al., 1998)

\begin{tabular}{|l|r|r|}
\hline \multirow{2}{*}{} & \multicolumn{2}{|c|}{ Type of manure } \\
\cline { 2 - 3 } & Layer & Broiler \\
\hline Nutrients (\%) & 3.3 & 4.1 \\
\hline Nitrogen (N) & 2.9 & 2.1 \\
\hline Phosphorus (P) & 3.6 & 2.7 \\
\hline Potassium (K) & 1.0 & 0.73 \\
\hline Sulphur (S) & \multicolumn{3}{|}{} \\
\hline Trace elements (ppm) & 2.040 & 3.254 \\
\hline Iron (Fe) & 403 & 383 \\
\hline Zinc $(\mathrm{Zn})$ & 163 & 163 \\
\hline Copper $(\mathrm{Cu})$ & &
\end{tabular}

From an ecological viewpoint, organic amendments offer some advantages if compared to mineral fertilizers. In addition to nutrient supply, they improve soil structure, control erosion, and improve water-holding capacity. However, there are also some disadvantages, as unpleasant odours, high content of inorganic phosphorus, which exceeds the needs of plants, release of volatile and reactive organic compounds into the air, etc. The alternative use of poultry waste, as animal feed or as a source of energy, is rather limited due to contaminants and high moisture content. Farmers have to be aware of all these advantages and disadvantages in order to be able to find and adopt acceptable and sustainable solutions.

Environmentalists often treat poultry less environmental-friendly than other livestock productions, mainly because of the fact that birds' nutritional needs should be met exclusively by crops produced on arable land (since they cannot, unlike ruminants, digest cellulose and use less productive land). However, according to recent researches, where so called "cradle-to-grave" approach has 
been applied ${ }^{1}$ (Williams et al., 2006; Van der Sluis, 2007; De Vries and De Boer; 2010; Van Der Werf, 2010) poultry appears to be the most environmentally efficient of all livestock productions. In Table 2 main environmental burdens for different animal productions are given. One can see that poultry production (both meat and eggs) is more environmentally efficient than other meat productions. This is due, among other factors, very efficient feed conversation, high daily weight gain, and lower emission of enteric methane.

Table 2. Main environmental burdens of animal products (Van der Sluis, 2007)

\begin{tabular}{|c|c|c|c|c|c|c|}
\hline \multirow[t]{2}{*}{ Impact } & Beef & $\begin{array}{c}\text { Sheep } \\
\text { Meat }\end{array}$ & $\begin{array}{c}\text { Pig } \\
\text { Meat }\end{array}$ & $\begin{array}{c}\text { Poultry } \\
\text { Meat }\end{array}$ & \multirow{2}{*}{$\begin{array}{c}\text { Eggs } \\
(20,000)\end{array}$} & \multirow{2}{*}{$\begin{array}{c}\text { Milk } \\
(10,000 \text { l) }\end{array}$} \\
\hline & \multicolumn{4}{|c|}{ (per tonne of carcass weight) } & & \\
\hline Primary Energy used, GJ & 27 & 26 & 23 & 15 & 14 & 26 \\
\hline $\begin{array}{l}\text { Global warming potential }(\mathrm{GWP})^{*} \\
{\mathrm{t} \mathrm{CO}_{2} \text { equivalent }}^{*}\end{array}$ & 15 & 17 & 4.9 & 3.6 & 3.8 & 11 \\
\hline $\begin{array}{l}\text { Eutrophication potential }(\mathrm{EP})^{* *} \\
\mathrm{~kg} \mathrm{PO}_{4} \text { equivalent }\end{array}$ & 101 & 153 & 32 & 26 & 26 & 45 \\
\hline $\begin{array}{l}\text { Acidification potential (AP)*** } \\
\mathrm{kg} \mathrm{SO}_{2} \text { equivalent }\end{array}$ & 162 & 130 & 83 & 61 & 70 & 94 \\
\hline
\end{tabular}

*Impacts of $\mathrm{CO}_{2}, \mathrm{~N}_{2} \mathrm{O}, \mathrm{N}_{2} \mathrm{O}-\mathrm{N}$ and $\mathrm{CH}_{4}$ are aggregated and quantified in terms of $\mathrm{CO}_{2}$ equivalents

** $\mathrm{NO}_{3}$ and $\mathrm{PO}_{4}$ leaching to water and $\mathrm{NH}_{3}$ emissions to air are aggregated and quantified in terms of $\mathrm{PO}_{4}$ equivalents

$* * * \mathrm{NH}_{3}$ and $\mathrm{SO}_{2}$ (from fossil fuel combustion) emission are aggregated and quantified in terms of $\mathrm{SO}_{2}$ equivalents

\section{The differences in environmental impact of different poultry housing systems}

Interest in alternative housing systems is growing worldwide (Perić et al., 2007; Rodić, 2010a; Rodić 2010b). It is often thought that these systems are more environmental friendly. However, research done by Williams et al. (2006) has shown that free range and organic poultry production are more environmentally harmful than intensive production systems (Table 3 ).

Table 3. Comparison environmental burdens of different production systems (Wiliams et al., 2006)

\begin{tabular}{|c||c|c|c|c|c|c|}
\hline \multirow{2}{*}{\multicolumn{1}{|c||}{ Impact and land used }} & \multicolumn{3}{c|}{$\begin{array}{c}\text { Poultry meat systems } \\
\text { (per tonne) }\end{array}$} & \multicolumn{3}{c|}{$\begin{array}{c}\text { Egg production system } \\
\text { (per 20,000 eggs) }\end{array}$} \\
\cline { 2 - 7 } & Traditional & Free range & Organic & Cage & Free range & Organic \\
\hline Primary Energy used, GJ & 12 & 14.5 & 16 & 13.6 & 15.4 & 16.1 \\
\hline \hline Global worming potential (GWP) & 4.6 & 5.5 & 6.7 & 5.3 & 6.2 & 7.0 \\
\hline \hline Eutrophication potential (EP) & 49 & 63 & 86 & 75 & 80 & 102 \\
\hline Acidification potential (AP) & 173 & 230 & 264 & 300 & 312 & 344 \\
\hline \hline Land use, ha & 0.64 & 0.73 & 1.40 & 0.63 & 0.78 & 1.48 \\
\hline
\end{tabular}

${ }^{1}$ By LCA method, all inputs into on-farm production for the observed livestock commodities (meat, milk, and eggs) were tracked back to primary resources. All activities supporting farm production (feed production processing, machinery and fertiliser manufacture, fertility building and cover crops) were also included. 
While other field crops and animal products consume less primary energy and have less environmental burdens when grown organically, poultry meat and eggs are exceptions, because of the much lower bird performance (Perić et al., 2007) and low efficiency of feed conversion in alternative housing systems.

\title{
Conclusion
}

Since environmental burdens depend, to great extent, on chosen management practices, one can say that poultry industry will not threaten the environment only if both economically and environmentally acceptable management practices are applied. Unfortunately, it is still not the case and there are still many issues, related to environmental impact of poultry production, which have to be solved in the future (together with health and animal welfare issues). Unfortunately, existing scientific knowledge is sufficient for problem recognition, however it is still not capable of presenting a final solution. Farmers must be aware of ways in which their production threatens environment. Only thus, they will be able to find and adopt solutions that will provide both profitability and sustainability of poultry production.

\section{Acknowledgment}

Research was financed by the Ministry of Education and Science, Republic of Serbia, project TR 31033.

\section{Uticaj živinarske proizvodnje na životnu sredinu}

\author{
V. Rodić, L. Perić, M. Đukić-Stojčić, N. Vukelić
}

\section{Rezime}

Osnovni cilj koji se postavlja pred savremenu stočarsku proizvodnju je da na održiv način proizvede visokokvalitetne proteine životinjskog porekla. Održivost, međutim, nije lako definisati. To je složen pojam koji uključuje ekonomsku, socijalnu i ekološku dimenziju određene proizvodnje, u datom društveno-ekonomskom kontekstu. U ovom smislu, savremena živinarska proizvodnja ispunjava prve dve dimenzije - ona potrošačima obezbeđuje kvalitetan prehrambeni proizvod po pristupačnoj ceni, a proizvođačima pruža mogućnost stvaranja profita, uz stvaranje mogućnosti investiranja u čitavom lancu, doprinoseći na taj način razvoju lokalne ekonomije. Međutim, sa koncentracijom i specijalizacijom živinarske proizvodnje javljaju se i sve veći ekološki problemi. U poslednje dve decenije, uticaj živinarske proizvodnje na životnu sredinu privlači sve veću 
pažnju. Na proizvođače se danas, sa različitih strana, vrši sve veći pritisak da negativan uticaj na životnu sredinu svedu na minimum. Čini se da će glavni izazov pred proizvođačima u budućnosti biti upravo zadovoljavanje visokih ekoloških standarda. U radu su prikazani najznačajniji uticaji koje živinarska proizvodnja ima na životnu sredinu i razlike koje u ovom pogledu postoje između pojedinih sistema proizvodnje.

\section{References}

ATKINSON G., DIETZ S., NEUMAYER E. (2007): Handbook of Sustainable Development. Cheltenham: Edward Elgar.

BOGGIA A., POLOTTI L., CASTELLINI C. (2010): Environmental Impact Evaluation of Conventional, Organic and Organic-plus Poultry Production Systems Using Life Cycle Assessment. World's Poultry Science Journal, 66, 1, 95-114. BOLAN N.S., SZOGI A.A., CHUASAVATHI T., SESHADRI B., ROTHROCK M.J., PANNEERSELVAM P. (2010): Uses and management of poultry litter. World's Poultry Science Journal, 66, 673-698.

BOŠNJAK D., RODIĆ V. (2006): Zastupljenost stoke kao jedan od faktora stabilnosti prinosa u ratarskoj proizvodnji. Savremena poljoprivreda, 55, 1-2, 5561.

BOŠNJAK D., RODIĆ, V., SUPIĆ N. (2008): Proizvodni pokazatelji stočarske proizvodnje u Vojvodini. Savremena poljoprivreda, 57, 1-2, 62-70.

BOŠNJAK D., LUČIĆ Đ., RODIĆ V., ŽUTIĆ V. (2007): Organizacija proizvodnje i korišćenje stajnjaka u poljoprivredi AP Vojvodine. Savremena poljoprivreda, 56, 1-2, 189-197.

DALY H.E. (1996): Beyond Growth: The Economics of Sustainable Development, Beacon Press, Boston.

DE VRIES M., DE BOER I. (2010): Comparing environmental impact for livestock products: A review of life cycle assessments. Livestock Science, 128, 111.

DICK A.W., JOHNSON W.J., ECKERT J.D. (1998): Land Application of Poultry Litter. Ohio State University Extension Fact Sheet \#ANR-4-98. http://ohioline.osu.edu/anr-fact/0004.html

HEGG R. (2006): The future of animal agriculture and the environment, The John M. Airy Beef Cattle Symposium: Visions for Animal Agriculture and the Environment. January 2006, Kansas City, MO.

KOSTIĆ S., RODIĆ V. (2009): The P-S-R Framework and its modified (extended) versions as the environmental management means. Proceedings of the XIIIth International ECO-conference, Novi Sad, 23-26 September 2009, 429-436.

PERIĆ L., ĐUKIĆ-STOJČIĆ M., MILOŠEVIĆ, N. (2007): Sistemi držanja kokoši nosilja u skladu sa propisima EU. Živinarstvo, 8-9. 
NAHM K.H. (2000): A strategy to solve environmental concerns caused by poultry production. World's Poultry Science Journal, 56, 379-388.

OECD (2003): Using the pressure-state-response model to develop indicators of sustainability: OECD Framework for environmental indicators.

PERIĆ L., MILOŠEVIĆ N., TOLIMIR N., ŽIKIĆ D. (2007): Results of egg production in different housing systems, Biotechnology in Animal Husbandry, 23, 5-6, 497-520.

RAE N.A. (1999): Livestock and Environment, Report to the Foundation for Research Science and technology. The NZ Institute of Economics Research, Wellington

RODIĆ V. (2006): The influence of instruments for environmental protection to livestock production. Contemporary agriculture, 55, 1-2, 42-47.

RODIĆ V., BOŠNJAK D., VUKELIĆ N. (2007a): Sustainability of agricultural land management in the Autonomous Province of Vojvodina. Thematic Proceedings of the 100th EAAE Seminar, Novi Sad, 429-437.

RODIĆ V., LUČIĆ Đ., BOŠNJAK D. (1999): Prostorna i ekološka ograničenja razvoja stočarstva u naseljenim mestima Vojvodine. Zaštita životne sredine gradova i prigradskih naselja, Monografija, Ekološki pokret grada Novog Sada, 117-123.

RODIĆ V., PERIĆ L., PAVLOVSKI Z., MILOŠEVIĆ N. (2010a): Competitiveness of table eggs from non-cage housing systems. Biotechnology in Animal Housbandry, 26, 1-2, 117-128.

RODIĆ V., PERIĆ L., PAVLOVSKI Z., MILOŠEVIĆ N. (2010b): Improving the poultry sector in Serbia: major economic constraints and opportunities. Worlds Poultry Science Journal, 66, 2, 241-250.

RODIĆ V., SUPIĆ N., KOLAROV M. (2007b): Zastupljenost stoke kao indikator pritiska stočarske proizvodnje na životnu. Contemporary agriculture, 56, 3-4, 147157.

TABLER G.T. (2006): Poultry producers at environmental crossroads. Available at http://www.thepoultrysite.com/articles/737/poultry-producers-at-environmental-

crossroads

WIEBE VAN DER SLUIS (2007): Intensive poultry production better for global warming. World Poultry, 23, 12, 28-31. www.worldpoultry.net

WILliAMS, A.G., AUDSLEY E., SANDARS D.L. (2006): Determining the environmental burdens and resource use in the production of agricultural and horticultural commodities. Defra Research Project IS0205. Bedford: Cranfield University.

WOSSINK A., WEFERING F. (2003): Hot Spots in Animal Agriculture. Emerging Federal Environmental Policies and the Potential for Efficiency and Innovation Offsets, Int. J. Agricultural Resources, Governance and Ecology, 2, 3-4, 228-242. 